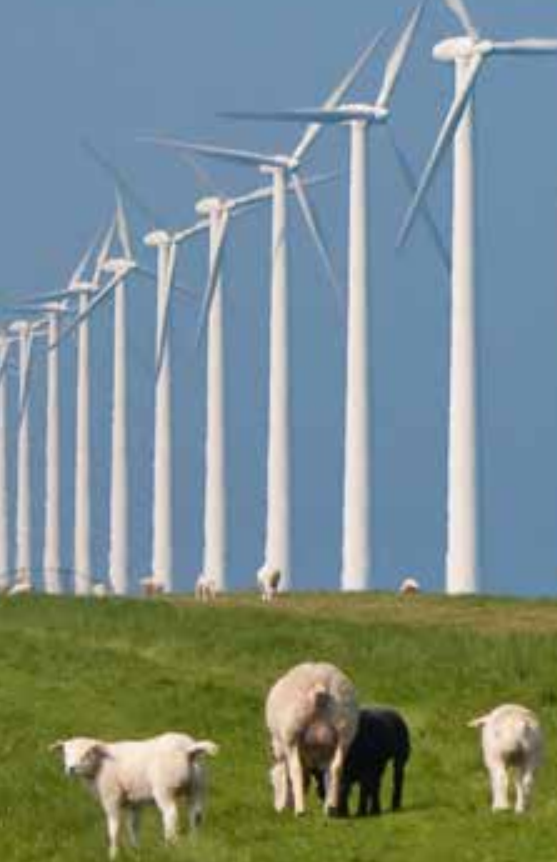




\section{Bedrijven en hun impact op en afhankelijkheid van natuurlijk kapitaal}

Marie-José Smits, Ernst Bos, Martijn van der Heide, Trond Selnes en Theo Vogelzang

Dit onderzoek is uitgevoerd door LEI Wageningen UR in opdracht van en gefinancierd door het ministerie van Economische Zaken, in het kader van het Beleidsondersteunend Onderzoek onderzoeksthema 'Natuurinclusieve economie en natuurcombinaties' (projectnummer BO-11-012-036)

LEI Wageningen UR

Wageningen, juni 2016

RAPPORT

LEI 2016-060

ISBN 978-94-6257-839-5 
Smits, Marie-José, Ernst Bos, Martijn van der Heide, Trond Selnes en Theo Vogelzang, 2016. Bedrijven en hun impact op en afhankelijkheid van natuurlijk kapitaal. Wageningen, LEI Wageningen UR (University \& Research centre), LEI Report 2016-060. 28 blz.; 2 fig.; 2 tab.; 12 ref.

Welke tools en data gebruiken bedrijven om hun impact op natuurlijk kapitaal te meten, en waar zitten nog hiaten wat betreft instrumentarium? De belangrijkste bevindingen, aan de hand van interviews, zijn: i) er wordt vooral gewerkt met LCA, ii) bedrijven met veel producten werken liever met keurmerken, iii) er is behoefte aan standaardisering op sectorniveau, iv) beschikbaarheid van data op gebiedsniveau is een knelpunt, v) de niet-koplopers zouden meer betrokken kunnen worden bij natuurlijk kapitaal.

What tools and data do companies use to measure their impact on natural capital, and what are the gaps in terms of instruments? The main findings, based on interviews are: i) companies mainly work with LCA ii) companies with many products prefer to work with labels, iii) there is a need for standardisation at the sector level, iv) availability of data at field level is a bottleneck, v) nonfrontrunners could be more involved in natural capital.

Trefwoorden: natuurlijk kapitaal, impact meten, bedrijven, tools en data

Dit rapport is gratis te downloaden op http://dx.doi.org/10.18174/384585 or at www.wageningenUR.nl/en/lei (under LEI publications).

(C) 2016 LEI Wageningen UR

Postbus 29703, 2502 LS Den Haag, T 07033583 30, E informatie.lei@wur.nl, www.wageningenUR.nl/lei. LEI is onderdeel van Wageningen UR (University \& Research centre).

\section{(cc) BY-NC}

LEI hanteert voor haar rapporten een Creative Commons Naamsvermelding 3.0 Nederland licentie.

(C) LEI, onderdeel van Stichting Dienst Landbouwkundig Onderzoek, 2016

De gebruiker mag het werk kopiëren, verspreiden en doorgeven en afgeleide werken maken. Materiaal van derden waarvan in het werk gebruik is gemaakt en waarop intellectuele eigendomsrechten berusten, mogen niet zonder voorafgaande toestemming van derden gebruikt worden. De gebruiker dient bij het werk de door de maker of de licentiegever aangegeven naam te vermelden, maar niet zodanig dat de indruk gewekt wordt dat zij daarmee instemmen met het werk van de gebruiker of het gebruik van het werk. De gebruiker mag het werk niet voor commerciële doeleinden gebruiken.

Het LEI aanvaardt geen aansprakelijkheid voor eventuele schade voortvloeiend uit het gebruik van de resultaten van dit onderzoek of de toepassing van de adviezen.

Het LEI is ISO 9001:2008 gecertificeerd.

LEI 2016-060 | Projectcode 2282700187

Foto omslag: Shutterstock 


\section{Inhoud}

$\begin{array}{ll}\text { Samenvatting } & \mathbf{5}\end{array}$

1

Inleiding $\quad 6$

1.1 Achtergrond en aanleiding $\quad 6$

$\begin{array}{lll}1.2 & \text { Vraagstelling } & 7\end{array}$

$\begin{array}{lll}1.3 & \text { Aanpak en opbouw rapport } & 8\end{array}$

$\begin{array}{ll}\text { Theorie, begripsbepaling en afbakening } & 9\end{array}$

$2.1 \quad$ Inleiding 9

2.2 Natuurlijk kapitaal, ecosysteemdiensten en biodiversiteit 9

2.3 De relatie tussen bedrijven en natuurlijk kapitaal $\quad 11$

$\begin{array}{lll}2.4 & \text { Resumerend } & 14\end{array}$

$3 \quad$ Praktijk: de rol van tools en data bij bedrijven $\quad 15$

3.1 Inleiding $\quad 15$

3.2 Wat en waarom: definitie en motivatie $\quad 15$

3.2.1 Wat: het begrip natuurlijk kapitaal $\quad 15$

3.2.2 Waarom: motivatie $\quad 15$

$\begin{array}{lll}3.3 & \text { Hoe: tools en data } & 16\end{array}$

$\begin{array}{lll}3.4 & \text { Wie: overheid versus bedrijfsleven } & 18\end{array}$

4

$\begin{array}{ll}\text { Conclusies } & 20\end{array}$

$\begin{array}{lll}4.1 & \text { Algemene inzichten } & 20\end{array}$

$\begin{array}{lll}4.2 & \text { Resultaten en vervolgstappen } & 20\end{array}$

$\begin{array}{ll}\text { Literatuur en websites } & 25\end{array}$

$\begin{array}{lll}\text { Bijlage } 1 \text { Afkortingen voluit geschreven } & 26\end{array}$ 



\section{Samenvatting}

Natuurlijk kapitaal is de verzamelnaam voor alle natuurlijke voorraden op aarde: het vormt de aanwezige hoeveelheid fysieke en natuurlijke hulpbronnen. Net als financieel kapitaal levert ook natuurlijk kapitaal rente als baten op, maar dan in de vorm van ecosysteemdiensten (Dirkx en De Knegt, 2014). Natuurlijk kapitaal is daarmee een voorraadgrootheid (stock), terwijl ecosysteemdiensten een stroomgrootheid (flow) zijn die bestaat uit baten die de natuur de mens levert. Sommige van deze baten zijn zichtbaar, zoals de productie van voedsel en hout. Andere zijn minder zichtbaar, zoals het vastleggen van $\mathrm{CO}_{2}$ in bossen, de zuivering van oppervlaktewater door een rietmoeras en het onderdrukken van plagen in de landbouw met natuurlijke vijanden. Natuurlijk kapitaal moet, net als andere vormen van kapitaal, verstandig gebruikt en beheerd worden om baten te kunnen blijven opleveren.

In dit onderzoek wordt een beeld geschetst van hoe bedrijven omgaan met tools en data voor het inschatten van hun afhankelijkheid van en/of impact op natuurlijk kapitaal. De belangrijkste bevindingen zijn:

1. Met name LCA (Levenscyclusanalyse) is in de interviews genoemd als tool waar mee gewerkt wordt. Het Natural Capital Protocol werd weinig genoemd. Daarbij moet aangetekend worden dat het Natural Capital Protocol nog in ontwikkeling is.

2. Bedrijven met een korte keten en een enkel product hebben veelal de mogelijkheid om hun beslag op natuurlijk kapitaal te meten. Echter, voor bedrijven aan het einde van een lange keten en met veel producten (bijvoorbeeld cateraars en supermarkten) is dit lastiger, zij zoeken veelal hun heil in keurmerken.

3. $\mathrm{Er}$ is behoefte aan gestandaardiseerde tools op sectorniveau. Standaardisering kan bijdragen aan de onderlinge vergelijkbaarheid.

4. De beschikbaarheid van (betrouwbare) data is een knelpunt. Met name beschikbaarheid van data op gebiedsniveau waar het gaat om biodiversiteit werd genoemd als knelpunt. Daarnaast is het de vraag hoe betrouwbaar bedrijfsdata zijn en hoe dit gecontroleerd kan worden.

5. In dit onderzoek zijn koplopers geïnterviewd. In de toekomst zouden ook overige bedrijven, dus zij die geen koploper zijn, meer betrokken kunnen worden bij natuurlijk kapitaal.

Het ministerie van Economische Zaken wil inzicht in hoe bedrijven omgaan met de term natuurlijk kapitaal en of er goede tools en data zijn voor de analyse. Kunnen de bedrijven met de bestaande tools uit de voeten, en wat verwachten ze bijvoorbeeld van de overheid? Om deze vraag te beantwoorden is allereerst op basis van de literatuur nader ingegaan op begripsbepaling omtrent natuurlijk kapitaal, evenals op de relatie tussen bedrijven en natuurlijk kapitaal. Vervolgens zijn tien interviews gehouden met bedrijven uit uiteenlopende sectoren, te weten: supermarktketen, energiesector, catering, adviesbureau, tapijtproducent, financiële instelling, diervoederproducent, NGO, zuivelproducent, en logistiek. De geïnterviewde bedrijven horen allen nadrukkelijk tot de koplopers wat aandacht voor natuurlijk kapitaal betreft. De interviews zijn geanalyseerd aan de hand van:

- definities en motivaties omtrent natuurlijk kapitaal

- de tools en data die gebruikt worden, en hiaten in de methodiek

- welke rol er vervolgens van de overheid wordt verwacht. 


\section{$1 \quad$ Inleiding}

\subsection{Achtergrond en aanleiding}

De essentie van dit onderzoek is een beeld te schetsen hoe bedrijven omgaan met tools en data voor het inschatten van hun afhankelijkheid van en/of impact op natuurlijk kapitaal. Menig bedrijf hanteert een tool c.q. methode om de interactie van het bedrijf met natuurlijk kapitaal te kunnen analyseren, en zo'n tool dient vervolgens gevuld te worden met data. De nadruk in dit onderzoek ligt op de beschikbaarheid van tools en de benodigde data, evenals op de wensen van bedrijven hieromtrent. Daarbij gaan we uit van de definitie die het Planbureau voor de Leefomgeving hanteert voor natuurlijk kapitaal, namelijk alle hernieuwbare en uitputbare hulpbronnen. ${ }^{1}$

Diverse bedrijven zoeken naar mogelijkheden om de impact van hun bedrijfsvoering op en afhankelijkheid van natuurlijk kapitaal te analyseren, om vervolgens deze impact en afhankelijkheid te kunnen terugdringen. Deze bedrijven zijn vaak ook actief in platforms zoals platform Biodiversiteit, Ecosystemen en Economie (BEE) en/of in internationale platforms en kunnen worden gezien als koplopers op dit gebied. Om bedrijven te faciliteren inzicht te krijgen in hun impact op, en afhankelijkheid van, grondstoffen is onder andere een database ontwikkeld door TNO. ${ }^{2}$ Momenteel wordt door het onderzoek- en adviesbureau CREM aan de hand van een pilot onderzocht of deze database kan worden aangevuld met data over de impact van grondstoffengebruik op biodiversiteit en ecosysteemdiensten. Ook is onlangs door I\&M de Atlas Natuurlijk Kapitaal (in ontwikkeling) gelanceerd met (geografische) informatie over ecosystemen en ecosysteemdiensten. Er gebeurt dus al veel. Tegelijkertijd is er behoefte aan meer inzicht in hoe bedrijven omgaan met de term natuurlijk kapitaal en of er goede tools en data zijn voor de analyse. Kunnen de bedrijven hiermee uit de voeten, en wat verwachten ze bijvoorbeeld van de overheid? Worden koplopers adequaat en efficiënt voorzien in de benodigde informatie om meer verantwoordelijkheid te kunnen dragen ten aanzien van natuurlijk kapitaal? En hoe kunnen de achterblijvers ook meegenomen worden in deze ontwikkeling?

De beleidscontext is vooral de Uitvoeringsagenda Natuurlijk Kapitaal (EZ en I\&M, 2013) en de Rijksnatuurvisie (EZ, 2014). In de Uitvoeringsagenda Natuurlijk Kapitaal stelt men dat het nu niet goed gaat met het natuurlijk kapitaal: er is een overexploitatie van ecosystemen en hun diensten en een onduurzaam gebruik van grondstoffen. Om deze bedreigingen aan te pakken, stelt men in de nota, is een transitie naar een duurzame wereldeconomie - met duurzamere productie, minder emissies en meer hergebruik - noodzakelijk om ons natuurlijk kapitaal voor toekomstige generaties zeker te stellen. Het beleid is erop gericht dat het Nederlands bedrijfsleven het natuurlijk kapitaal op waarde schat. Het kabinet stimuleert deze ontwikkeling door de ondersteuning van het Platform BEE en de initiatieven daar om de impact van bedrijven op de biodiversiteit in beeld te brengen en mee te laten wegen in het ondernemen. Ook stimuleert het kabinet dat bedrijven het natuurlijk kapitaal in hun boekhouding meenemen, zoals het in 2014 opgezette initiatief van een biodiversiteitsbenchmarking tussen bedrijven en sectoren. Verder stimuleert het kabinet het initiatief True Pricing, waarbij naast de normale marktprijs een prijs in termen van natuurlijk kapitaal op het product wordt vermeld. Die prijs biedt inzicht in alle werkelijke kosten, bijvoorbeeld voor het gebruik van biodiversiteit. Het resultaat is veel meer transparantie over de kosten die niet in de marktprijs van een product zijn opgenomen. Daarnaast werkt het kabinet aan een Green Deal 'samenwerken aan transparantie van natuurlijk kapitaal en sociaal kapitaal'. Bedrijven moeten in toenemende mate laten zien wat ze doen, niet alleen het financieel kapitaal, of sociaal kapitaal, maar ze moeten ook rapporteren over het natuurlijk kapitaal. Als de bedrijven dit doen, dan ontstaat een zekere mate van transparantie.

\footnotetext{
1 Binnen het denken over natuurlijk kapitaal bestaat overigens discussie over wat hier onderdeel van uitmaakt. Zo neemt de Natural Capital Coalition delfstoffen als fossiele brandstoffen wel mee in haar definitie van natuurlijk kapitaal.

2 TNO, 2014, Materialen in de Nederlandse Economie - een beoordeling van de kwetsbaarheid.
} 


\subsection{Vraagstelling}

De kernvraag is welke issues er spelen bij bedrijven als het gaat om de informatievoorziening en het informatiegebruik ten behoeve van het duurzamer omgaan met natuurlijk kapitaal; welke kansen en barrières zijn er daarbij om de impact op en afhankelijkheid van natuurlijk kapitaal te verminderen, en welke rol kan de overheid spelen om het benutten van kansen en wegwerken van barrières te bevorderen?

De aanpak is om aan de hand van interviews bij bedrijven te inventariseren wat zij als belangrijkste hindernissen ervaren wanneer ze hun afhankelijkheid van en impact op natuurlijk kapitaal willen verminderen. Hierbij focussen we met name op de behoefte aan en het gebruik van tools en data niet alleen op bedrijfsniveau, maar nadrukkelijk ook op ketenniveau. Sluiten beschikbare tools aan op de methoden die bedrijven (zouden willen) gebruiken? Is de beschikbaarheid van data een hindernis? En zo ja, welk type data ontbreekt vooralsnog?

Dit onderzoek heeft het karakter van een verkenning, waarbij rekening gehouden wordt met de mogelijke behoefte aan een verdieping in een latere fase. Daartoe zal in dit onderzoek ook een indruk moeten worden verkregen in welke mate bedrijven bereid zijn mee te werken aan verder onderzoek naar de wijze waarop zij omgaan met natuurlijk kapitaal en hoe de vraagstelling eventueel zou moeten worden aangepast om de interesse van bedrijven in zulk onderzoek te vergroten.

\section{Kennisvragen}

Bij de interviews zijn medewerkers betrokken van bedrijven en intermediairs die verantwoordelijkheid, c.q. expertise hebben omtrent de omgang van hun organisatie met natuurlijk kapitaal. Daarmee wordt beoogd antwoord te krijgen op kennisvragen over belemmeringen en kansen ten aanzien van:

\section{Tools en data}

Voor het realiseren van impact- en afhankelijkheidsvermindering op natuurlijk kapitaal kan door bedrijven gebruik gemaakt worden van tools en data: eerst wordt bepaald welke tool geschikt is, vervolgens worden data verzameld voor doorrekening middels de tool. Bij tools kan gedacht worden aan LCA (Levenscyclusanalyse) waarmee de milieubelasting van een product gedurende de hele levenscyclus wordt bepaald, en andere tools zoals beschreven door de World Business Council for Sustainable Development (WBCSD: rapport Eco4Biz). In de kern gaat het er dus om of en in hoeverre het huidige aanbod van tools en data aansluit bij de wensen en voorkeuren van bedrijven. Daarbij is ook van belang dat de volledige keten bestudeerd moet worden en dus dat data voor de hele keten beschikbaar moeten zijn.

Vragen hierbij zijn: Aan welke tools hebben bedrijven behoefte? Hoe wordt daarin voorzien? Welke hiaten zijn er? En hoe gaan ze om met de data? Wat zijn de kansen/uitdagingen/gevaren van 'big data'? Ervaren de bedrijven veranderingen over tijd, zijn er bijvoorbeeld meer kansen wat betreft dataverzameling en data-uitwisseling nu dan in het verleden, bijvoorbeeld door technische ontwikkelingen? Hoe worden data uitgewisseld tussen verschillende ketenonderdelen? Hoe zit het met de transparantie in de keten?

\section{Overheid versus bedrijfsleven}

Het ministerie van Economische Zaken wil bevorderen dat bedrijven hun verantwoording nemen voor wat betreft hun afhankelijkheid van en impact op natuurlijk kapitaal. Om dit meer kans van slagen te geven kunnen de bedrijven die hiermee aan de slag willen op bepaalde punten worden ondersteund, bijvoorbeeld wat betreft de ontwikkeling van tools, standaarden en datavoorziening.

Vragen hierbij zijn: Waar ondervinden de bedrijven belemmeringen waarbij de overheid een rol zou kunnen spelen deze te reduceren? Welk beleid (policies, measures, opportunities) kan ingezet worden om bedrijven te ondersteunen in hun zoektocht naar data wat betreft hun impact op natuurlijk kapitaal? Hoe gaan bedrijven om met betrouwbaarheid van data? Wat kan de overheid doen ten behoeve van ketentransparantie? Loopt men tegen problemen aan wat betreft internationalisering van ketens, en dus van data? Is er wetgeving waar men tegenaan loopt? Is de regelgeving een barrière, of 
zit er ook voordelen aan? Ervaren de bedrijven veranderingen over tijd, zijn er bijvoorbeeld meer kansen nu dan in het verleden?

\subsection{Aanpak en opbouw rapport}

In hoofdstuk 2 van dit rapport wordt op basis van de literatuur nader ingegaan op begripsbepaling omtrent natuurlijk kapitaal, evenals op de relatie tussen bedrijven en natuurlijk kapitaal. Vervolgens brengt hoofdstuk 3 op basis van de uitgevoerde interviews in beeld in hoeverre - en hoe - bedrijven en intermediairs in de praktijk omgaan met tools en data ten behoeve van natuurlijk kapitaal. Ook wordt ingegaan op de wensen en voorkeuren van bedrijven omtrent tools en data. Hiermee wordt inzicht gegeven in:

- definities en motivaties omtrent natuurlijk kapitaal

- de tools en data die gebruikt worden, en hiaten in de methodiek

- welke rol er vervolgens van de overheid wordt verwacht.

In hoofdstuk 4 worden de belangrijkste conclusies en bevindingen samengevat.

In deze studie wordt expliciet onderscheid gemaakt tussen tools en data. Met tools wordt bedoeld methoden om de afhankelijkheid van een bedrijf, c.q. de impact op natuurlijk kapitaal mee te kunnen bepalen. Voorbeelden van tools zijn het Natural Capital Protocol en de Levenscyclusanalyse. Door vervolgens data te verzamelen voor de grootheden van een tool, wordt de impact van een bedrijf op het natuurlijk kapitaal feitelijk berekend. Ten slotte ligt de nadruk van het onderzoek bij bedrijven: de consumentenkant is alleen betrokken wanneer dit relevant is. 


\section{Theorie, begripsbepaling en afbakening}

\section{$2.1 \quad$ Inleiding}

De capaciteit van de aarde is eindig: natuurlijke voorraden kunnen opraken, en de opnamecapaciteit van de atmosfeer en onze natuurlijke omgeving kent haar grenzen. Vandaar dat er steeds vaker wordt gesproken over de overgang van een lineaire naar een circulaire economie. In de lineaire economie worden grondstoffen gewonnen om goederen te produceren voor de consument, die ze na gebruik veelal weggooit. Gezien de eindigheid van het voortbestaan van onze aarde wordt er steeds naarstiger gezocht naar alternatieven voor dit lineaire businessmodel. Met als doel nieuwe economische ontwikkeling hand in hand te laten gaan met bewust en slim gebruik van het natuurlijk kapitaal. In de circulaire economie wordt in de ontwerpfase al naar manieren gezocht waarmee bestanddelen van een product na gebruik opnieuw als zo hoogwaardig mogelijke grondstoffen of componenten in het productieproces ingezet kunnen worden. Het voordeel hiervan is minder winning van nieuwe grondstoffen (en dus minder vervuiling en minder energieverbruik, maar ook een lagere afhankelijkheid van buitenlandse grondstoffen), en minder afval van afgedankte consumptiegoederen. Bedrijven spelen een cruciale rol bij de omschakeling van een lineaire naar een circulaire economie.

In dit hoofdstuk gaan we dieper in op de begrippen die centraal staan in dit onderzoek, en de onderlinge verhouding er tussen. Daartoe gaan we eerst in op de termen natuurlijk kapitaal, ecosysteemdiensten en biodiversiteit, en hoe deze drie begrippen zich tot elkaar verhouden (paragraaf 2.2). Vervolgens komt de veelzijdige relatie tussen kernbegrippen bedrijven en natuurlijk kapitaal aan bod (paragraaf 2.3 ). Tot slot vat paragraaf 2.4 de belangrijkste bevindingen van dit hoofdstuk samen.

\subsection{Natuurlijk kapitaal, ecosysteemdiensten en biodiversiteit}

Goederen die worden gebruikt voor de productie van consumptiegoederen, worden 'kapitaalgoederen' genoemd. Zij zijn daarmee, naast arbeid en grond, input voor het productieproces en worden ook wel productiefactoren genoemd. Er zijn meerdere categorieën kapitaalgoederen, zoals fysiek kapitaal en financieel kapitaal, maar wij richten ons in deze studie specifiek op natuurlijk kapitaal.

Natuurlijk kapitaal is de verzamelnaam voor alle natuurlijke voorraden op aarde: het vormt de aanwezige hoeveelheid fysieke en natuurlijke hulpbronnen. Net als financieel kapitaal levert ook natuurlijk kapitaal rente als baten op, maar dan in de vorm van ecosysteemdiensten (Dirkx en De Knegt, 2014). Natuurlijk kapitaal is daarmee een voorraadgrootheid (stock), terwijl ecosysteemdiensten een stroomgrootheid (flow) zijn die bestaat uit baten die de natuur de mens levert. Sommige van deze baten zijn zichtbaar, zoals de productie van voedsel en hout. Andere zijn minder zichtbaar, zoals het vastleggen van $\mathrm{CO}_{2}$ in bossen, de zuivering van oppervlaktewater door een rietmoeras en het onderdrukken van plagen in de landbouw met natuurlijke vijanden. Natuurlijk kapitaal moet net als andere vormen van kapitaal, verstandig gebruikt en beheerd worden om baten te kunnen blijven opleveren.

Natuurlijk kapitaal is daarmee een breed begrip, en laat zich niet altijd even makkelijk operationaliseren. Vandaar dat afbakening is gewenst. Het Planbureau voor de Leefomgeving (PBL) betrekt binnen het programma Natuurlijk Kapitaal Nederland (NKN) in haar analyses van natuurlijk kapitaal alleen de hernieuwbare en uitputbare hulpbronnen: zie Figuur 1. Niet-levende hulpbronnen, zoals olie, maar ook zonne- en windenergie, worden binnen dit programma door het PBL buiten 
beschouwing gelaten. Natuurlijk kapitaal kan, net als elk kapitaal, zodanig beheerd worden dat zijn waarde behouden blijft, groeit, of uitgeput raakt. Een voorbeeld van benutting waarbij de waarde behouden blijft of zelfs groeit is duurzame visserij waarbij de visstand op peil blijft. ${ }^{3}$

Deze afbakening wordt inmiddels ook door anderen overgenomen. Zo hanteren Het Groene Brein, MVO Nederland en Platform Biodiversiteit, Ecosystemen en Economie (2015) in hun gezamenlijke visiedocument 'Natuurlijk Kapitaal: Een Gedeelde Basis' een vergelijkbare definitie van natuurlijk kapitaal. Schematisch ziet die eruit als in Figuur 1.

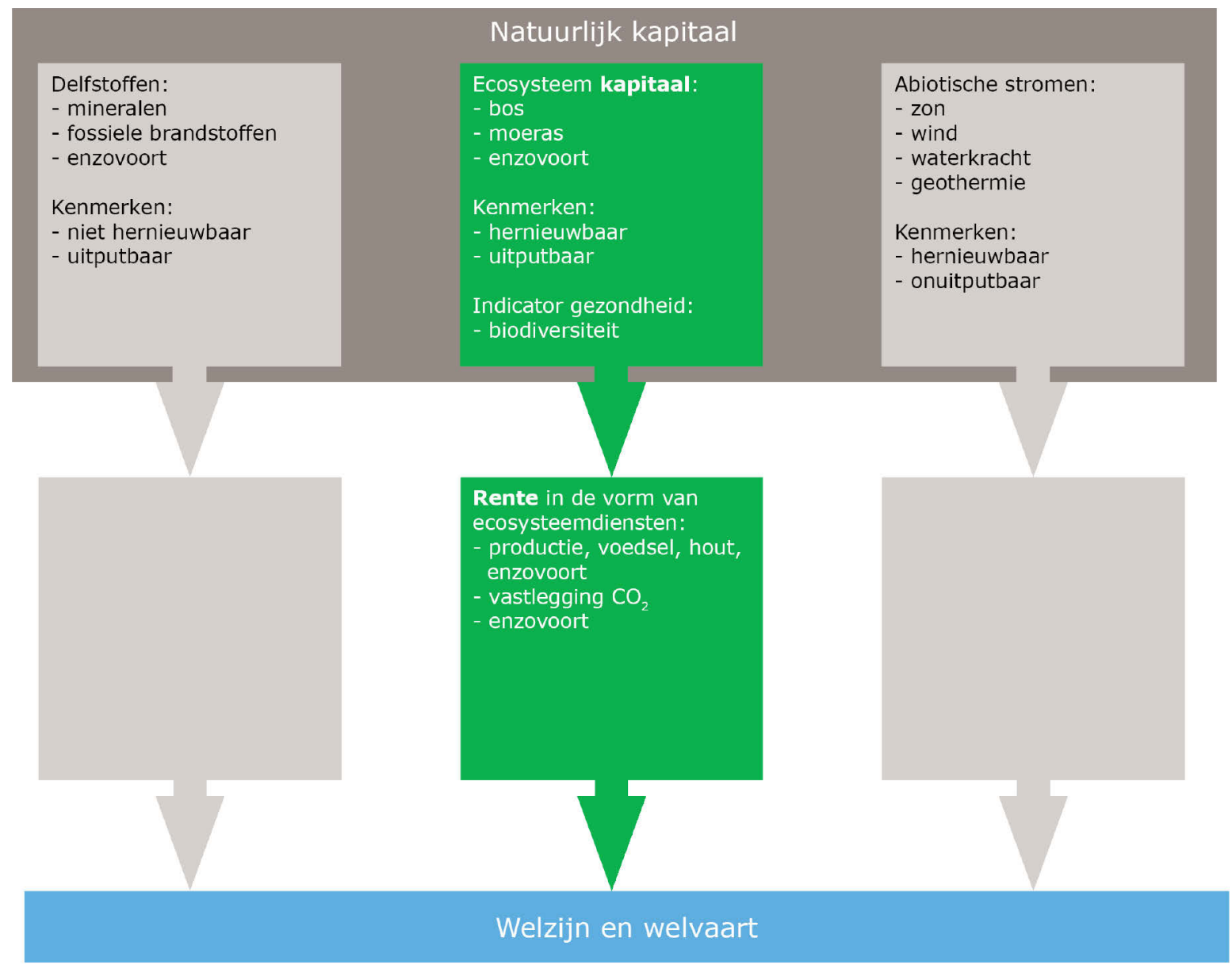

Figuur 1 Natuurlijk Kapitaal en ecosysteemdiensten Bron: gebaseerd op Oosterhuis en Ruijs (2015).

Dat neemt niet weg dat discussie blijft bestaan over de vraag of delfstoffen, zoals fossiele brandstoffen en metalen, onderdeel zijn van natuurlijk kapitaal. De Natural Capital Coalition neemt ze nadrukkelijk wel mee in haar definitie van natuurlijk kapitaal. ${ }^{4}$ Volgens haar protocol omvat natuurlijk kapitaal zowel hernieuwbare als niet-hernieuwbare hulpbronnen.

Uit de Uitvoeringsagenda Natuurlijk Kapitaal (Ministerie van EZ, 2013) en uit de Rijksnatuurvisie (Ministerie van EZ, 2014) blijkt dat het kabinet met behoud van natuurlijk kapitaal in elk geval ook het behoud van biodiversiteit wil realiseren. Het kabinet ziet daarmee bescherming van natuurlijk kapitaal als middel om de biodiversiteit te behouden. Biodiversiteit is de rijkdom aan levende natuur en weerspiegelt de variëteit (diversiteit) in levensvormen. Het is een breed begrip, want biodiversiteit gaat niet alleen over de diversiteit in soorten, maar ook over genetische diversiteit en de

\footnotetext{
3 Bron: http://themasites.pbl.nl/natuurlijk-kapitaal-nederland/achtergronden/wat-is-natuurlijk-kapitaal

4 Zie: http://www. naturalcapitalcoalition.org/why-natural-capital/natural-capital.html
} 
verscheidenheid aan ecosystemen (Van der Heide et al., 2015). Het ecosysteem wordt (naast andere natuurlijke hulpbronnen) als onderdeel van het natuurlijk kapitaal beschouwd, terwijl - zoals hierboven al aangegeven - ecosysteemdiensten de rente zijn die dit kapitaal (potentieel) oplevert, oftewel de vruchten die ervan kunnen worden geplukt. Maar biodiversiteit en natuurlijk kapitaal zijn niet aan elkaar gelijk. De relatie tussen de twee begrippen is complex. Er zijn namelijk ook wetenschappers die diversiteitsindexen juist als indicator zien voor de gezondheid van een ecosysteem: zie bijvoorbeeld Jorgensen et al. (2005). In deze studie interpreteren we de relatie tussen de begrippen ecosysteem en biodiversiteit daarmee eenvoudigheidshalve als volgt:

- Een ecosysteem wordt gevormd door de wisselwerking tussen alle organismen en de abiotische omgeving binnen een zekere geografische of anderszins afgebakende eenheid.

- Biodiversiteit is een begrip voor de graad van verscheidenheid aan levensvormen (soorten, genen enzovoort) binnen een gegeven ecosysteem. Biodiversiteit zou daarmee beschouwd kunnen worden als een indicator voor de gezondheid van een ecosysteem.

De gangbare veronderstelling is dat gebieden met een hoge biodiversiteit een ruimer aanbod aan ecosysteemdiensten hebben dan gebieden met weinig biodiversiteit. Bovendien, gebieden met een rijke biodiversiteit zijn stabieler dan gebieden met een beperkte biodiversiteit. Onduidelijk is nog of alle planten- en diersoorten nodig zijn om de beoogde ecosysteemdiensten te leveren. Er zijn aanwijzingen voor niet-lineaire relaties tussen beide (Oosterhuis en Ruijs, 2015). Dat betekent dat de huidige (beleids)aandacht voor natuurlijk kapitaal, en de daaruit voortvloeiende baten van natuur, niet als vanzelfsprekend hoeft te leiden tot behoud van al die biodiversiteit. Een voorbeeld ter illustratie: een intensief gebruik van productiediensten, bijvoorbeeld voor voedselproductie, kan een negatieve impact hebben op biodiversiteit en kan het aanwezige natuurlijk kapitaal uitputten. Andere ecosysteemdiensten daarentegen zijn juist positief voor biodiversiteit (met name regulerende en habitat diensten), of zijn afhankelijk van een bepaalde mate van biodiversiteit.

\subsection{De relatie tussen bedrijven en natuurlijk kapitaal}

Natuurlijk kapitaal levert hulpbronnen en diensten voor de economie. Een duurzaam gebruik ervan betekent dat economische sectoren en hun bedrijven ook op de langere termijn over voldoende hulpbronnen kunnen blijven beschikken. Inmiddels lijken steeds meer bedrijven in Nederland natuurlijk kapitaal in hun beslissingen mee te wegen (Van Leenders en Bor, 2014), of raken ze betrokken en dragen bij aan natuur in Nederland (Breman et al., 2014). Maar hoe verhouden bedrijven en natuurlijk kapitaal zich tot elkaar? Kort samengevat laat deze relatie zich als volgt illustreren (zie Figuur 2). 


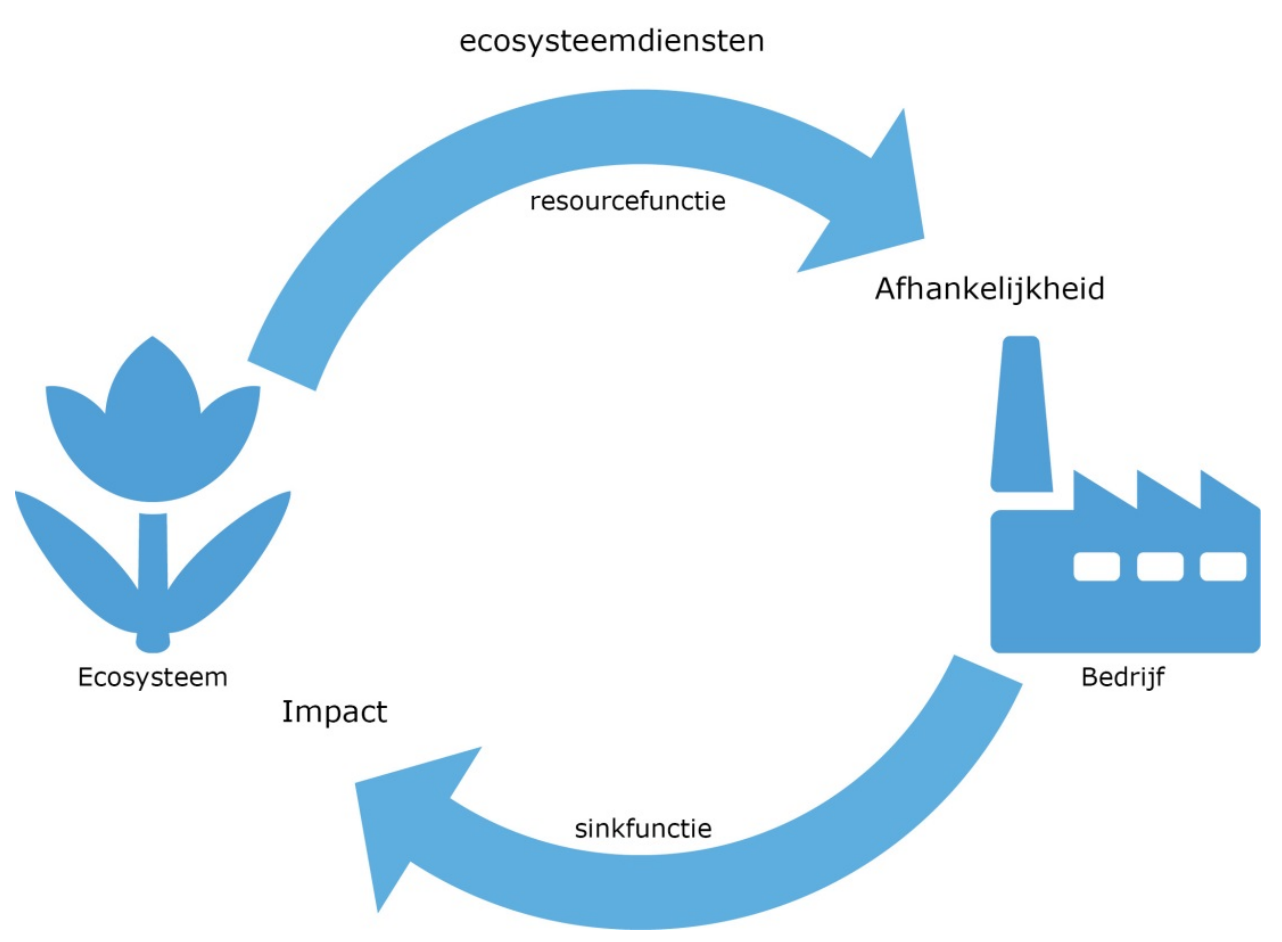

Figuur 2 Relatie tussen natuurlijk kapitaal en bedrijf a)

a) Een bedrijf heeft impact op ecosystemen, de zogenoemde sinkfunctie. En bedrijven zijn afhankelijk van ecosystemen: de resourcefunctie. De resourcefunctie wordt ook wel ecosysteemdiensten genoemd.

Bron: gebaseerd op Van Leenders en Bor (2014).

Kortom, een bedrijf is voor zijn bedrijfsvoering afhankelijk van natuurlijk kapitaal en/of heeft er impact op, bijvoorbeeld via emissies en afval. In meer detail, en van belang voor deze studie, geldt het volgende:

- Ieder bedrijf is in meer of mindere mate afhankelijk van natuurlijk kapitaal. Daarbij zijn enkele voorbeelden van ecosysteemdiensten die het natuurlijk kapitaal de bedrijven biedt: voedsel, biochemische materialen, waterzuivering, bestuiving en $\mathrm{CO}_{2}$-opslag. Het natuurlijk kapitaal dat bedrijven daarmee in hun productieproces benutten wordt ook wel de resourcefunctie genoemd. Alleen: bedrijven zijn zich lang niet altijd bewust van deze afhankelijkheid. Bijvoorbeeld omdat de leveringszekerheid van grondstoffen (nog) niet ter discussie staat en de afname van diensten nog niet voelbaar is. Deze situatie is echter snel aan het veranderen. Voor bedrijven is het daarom belangrijk te weten wat de relatie met natuurlijk kapitaal is en waar zich eventuele risico's kunnen voordoen.

- Het verlies aan natuurlijk kapitaal vormt een bedrijfseconomisch risico. Bijvoorbeeld doordat grondstoffen schaarser worden, ecosysteemdiensten die de natuur levert geld gaan kosten (zoals bestuiving, waterzuivering, bodemvruchtbaarheid) of de reputatie van een bedrijf in het geding komt. ${ }^{5}$ Sommige van deze risico's onttrekken zich mogelijk aan het zicht van een bedrijf doordat ze in de keten plaatsvinden of nu nog niet merkbaar zijn. Inzicht in deze risico's is echter belangrijk om tijdig te kunnen handelen. Door tijdig actie te ondernemen kunnen ook kansen ontstaan.

- Inzet op natuurlijk kapitaal biedt concrete kansen, zoals het profiteren van nieuwe ontwikkelingen (productinnovatie ${ }^{6}$ en nieuwe markten); het anticiperen op kostenstijgingen van grondstoffen (via

5 De meest voorkomende risico's, aldus Platform Biodiversiteit, Ecosystemen en Economie (Platform BEE) zijn:

(i) operationele risico's door een gebrek aan leveringszekerheid van grondstoffen en ecosysteemdiensten waarvan een bedrijf afhankelijk is; (ii) niet kunnen voldoen aan toenemende wet- en regelgeving op het gebied van natuur en biodiversiteit; (iii) reputatierisico als gevolg van 'milieuproblemen' rond een bedrijf of bij zijn toeleveranciers; (iv) niet tijdig inspelen op een veranderende marktvraag als gevolg van een kritischer wordende consument; en ( $v$ ) niet kunnen voldoen aan de eisen van financiële instellingen, bijvoorbeeld bij kredietverlening. Zie:

http://www. platformbee.nl/risicos/.

${ }^{6}$ Denk aan 'biomimicry': bij het ontwerpen leren van de natuur. 
inkoop en productontwerp); het versterken van de naam en reputatie van het bedrijf als groen, verantwoordelijk en milieuvriendelijk (marketing en communicatie); het samen met anderen aantrekkelijk maken van de fysieke leefomgeving, de zogeheten 'pro-biodiversiteit bedrijfsactiviteiten' (aantrekkelijke werkgever en buurman); en realiseren van concurrentievoordeel door de focus op duurzaamheid.

- Ieder bedrijf heeft een zekere impact op natuurlijk kapitaal, bijvoorbeeld via emissies naar bodem, water of lucht, of door landgebruik en het gebruik van natuurlijke grondstoffen zoals water, hout en landbouwproducten. Het kan gaan om impact door het eigen bedrijf, maar ook door zijn toeleveranciers. Deze impact wordt ook wel de sinkfunctie genoemd. Wanneer bekend is hoe bedrijfseconomische activiteiten van invloed zijn op het natuurlijke kapitaal (hier en in de keten), dan kan de druk van deze activiteiten op dit kapitaal mogelijk nog verder verminderen en misschien zelfs een positieve bijdrage leveren.

En hoewel natuurlijk kapitaal steeds vaker in bedrijfseconomische beslissingen wordt meegenomen, zijn er desondanks tal van redenen te bedenken waarom dit nog geen gemeengoed is:

1. Er ontbreekt relevante kennis over het belang ervan voor het bedrijf.

2. Het blijkt lastig de kosten voor onderhoud van natuurlijk kapitaal terug te verdienen.

3. Het ontbreekt aan samenwerking tussen de partijen die gezamenlijk profiteren van het geheel aan ecosysteemdiensten. ${ }^{7}$

4. Institutionele condities (wetgeving, vergunningseisen en juridische kaders) die incentives geven voor een ander gebruik van natuurlijk kapitaal en ecosysteemdiensten, ontbreken.

Er is evenwel niet één standaardoplossing om al deze belemmeringen ongedaan te maken. Waar we ons in dit onderzoek op richten is op de rol van tools en data in het slechten of verminderen van deze belemmeringen. Een voorbeeld ter illustratie: Levenscylusanalyse (LCA) is een gevestigde wetenschappelijke methode om te beoordelen welke impact een product heeft op het milieu. Het bestudeert de impact gedurende het leven van een product - vanaf de winning en productie van ruwe grondstoffen tot de vervaardiging, het transport, gebruik, onderhoud en de afvalverwerking (Van Arkel en Jonker, 2012).

Voor dit onderzoek is van belang hoe biodiversiteitsaspecten en de impact van het productieproces op natuurlijk kapitaal in een LCA kunnen worden geïntegreerd en welke data hiervan van belang zijn. Minder (of niet) van belang voor dit onderzoek is de impact van natuurbeleid op bedrijven. We gaan, met andere woorden, niet onderzoeken hoe monitoring en data een rol spelen bij het kwantificeren van de effecten van natuurbeleid op bedrijfseconomische activiteiten.

Inzichten in welke issues er in de praktijk spelen bij bedrijven aangaande informatievoorziening -en gebruik omtrent natuurlijk kapitaal, worden in deze studie dus verkregen aan de hand van interviews. Eerder zijn Van den Burg en Bogaardt (2014) ook middels het interviewen van bedrijven ingegaan op de rol die zij hebben bij het beschermen van biodiversiteit en ecosystemen. In de studie van Van den Burg en Bogaardt (2014) stond echter niet de rol van tools en data centraal, maar meer het verschil in terminologieën en rollen die overheden en bedrijven voorzagen bij de bescherming van ecosystemen. Uit deze studie kwam onder meer naar voren dat bedrijven - meer dan overheden en NGO's - een functioneel beeld hebben ten aanzien van biodiversiteit. Denk aan het beschikbaar blijven van natuurlijke hulpbronnen voor voedselproductie. Bedrijven wijzen ook - weer meer dan overheden en NGO's dat doen - op het publieke karakter van biodiversiteit.

Hoewel de beide studies een duidelijk verschillende insteek hebben, zijn er ook een paar overeenkomsten. In Van den Burg en Bogaardt (2014) gaven bedrijven aan dat ze niet goed weten wat hun impact op biodiversiteit is. Ditzelfde probleem zien we ook terug bij de bedrijven die wij hebben geïnterviewd. Verder blijkt zowel uit de interviews die wij hebben uitgevoerd als die van

\footnotetext{
7 Een mogelijk achterliggende reden hiervoor kan zijn als het voor een individueel bedrijf loont om een zogenaamde 'freerider' te zijn. Als je als individueel bedrijf meer baten van ecosysteemdiensten onttrekt dan natuurlijk kapitaal bij kan produceren, zijn de kosten daarvan voor de maatschappij misschien wel groot, maar als voor dat individuele bedrijf de kosten kleiner dan de baten heeft het bedrijf geen directe prikkel om minder ecosysteemdiensten te onttrekken.
} 
Van den Burg en Bogaardt (2014) dat bedrijven van overheden verwachten dat zij - al dan niet in samenwerking met de wetenschap - methoden en standaarden ontwikkelen om de interactie met natuurlijk kapitaal beter te kunnen meten. Voor het vervolgens uitvoeren van dergelijke methoden werd vanuit beide surveys gewezen op de mogelijke rol van intermediairs hierin.

\section{$2.4 \quad$ Resumerend}

In dit hoofdstuk is een overzicht gegeven van wat vanuit beleid en onderzoek wordt verstaan onder begrippen als natuurlijk kapitaal, ecosysteem(diensten) en biodiversiteit, evenals hoe deze begrippen zich tot elkaar verhouden. Ook is, op basis van literatuur, ingegaan op de relatie tussen bedrijven en natuurlijk kapitaal. Naast het feit dat bedrijven afhankelijk zijn van natuurlijk kapitaal en met hun productieprocessen er ook impact op kunnen hebben, gaat het daarbij ook om risico's en kansen.

In het volgende hoofdstuk wordt ingegaan op de vraag hoe bedrijven zélf hier tegen aankijken, en welke rol tools en data voor bedrijven hebben als bron van informatie over hun relatie met natuurlijk kapitaal. 


\section{Praktijk: de rol van tools en data bij bedrijven}

\subsection{Inleiding}

In dit hoofdstuk gaan we in op de uitkomsten van interviews met een aantal bedrijven. We gaan eerst in op wat en waarom; wat verstaan bedrijven onder natuurlijk kapitaal en wat is de motivatie achter hun handelen op dat gebied (paragraaf 3.2). Daarna kijken we naar het hoe, dus hoe zij omgaan met tools en data (paragraaf 3.3). Vervolgens gaat het om de vraag welke rol bedrijven van overheden verwachten (paragraaf 3.4). Om een antwoord te kunnen geven op deze vragen zijn van de volgende bedrijven c.q. organisaties experts, c.q. verantwoordelijken voor natuurlijk kapitaal geïnterviewd:

- vier bedrijven uit de voedingsindustrie: een supermarktketen, een diervoederproducent, een cateringbedrijf en een zuivelproducent

- twee intermediairs die bedrijven ondersteunen met modellen: een consultancybedrijf en een NGO;

- een tapijtproducent

- een financiële instelling

- een energieproducent

- een logistieke dienstverlener. ${ }^{8}$

De selectiecriteria daarbij waren dat:

- het koplopers moesten zijn op het gebied van natuurlijk kapitaal

- een breed scala aan typen bedrijven zou worden betrokken.

Het gaat hier dus nadrukkelijk om vooroplopers met een meer dan gemiddelde aandacht voor natuurlijk kapitaal. Verder worden de bevindingen uit de interviews geanonimiseerd weergegeven.

\subsection{Wat en waarom: definitie en motivatie}

\subsubsection{Wat: het begrip natuurlijk kapitaal}

Hoewel een aantal bedrijven een vrij breed begrip van natuurlijk kapitaal hanteerde, kwam de definitie van de meeste bedrijven goeddeels overeen met die van het PBL. Accentverschillen in de definitie van natuurlijk kapitaal kunnen samenhangen met het type bedrijf en zijn producten. Wanneer een bedrijf wereldwijd produceert, ligt bijvoorbeeld het uit willen sluiten van kinderarbeid als onderdeel van natuurlijk kapitaal meer voor de hand dan wanneer een bedrijf voornamelijk nationaal produceert. Verder is uit de interviews niet gebleken dat bedrijven expliciet onderscheid maken tussen natuurlijk kapitaal (ecosystemen) en rente (ecosysteemdiensten). Ten slotte noemde alleen de NGO de term Atlas Natuurlijk Kapitaal.

\subsubsection{Waarom: motivatie}

De vraag is vervolgens waarom bedrijven zich inzetten voor het behoud van natuurlijk kapitaal. Speelt bijvoorbeeld imago een rol of vooral ook hun 'licence to produce'?

Imago speelt een rol, maar het beeld is wel meer genuanceerd dan enkel een imagokwestie. De mate waarin imago een motivatie was verschilde bijvoorbeeld al tussen bedrijven binnen de voedingsindustrie. Zo was voor één voedingsbedrijf - de supermarktketen - het voorkomen van imagoschade een heel belangrijk argument. Met name het voorkomen van kinderarbeid was voor dit

\footnotetext{
8 Het betreft een nv.
} 
bedrijf prioritair. Ook bij een ander internationaal producerend voedingsbedrijf - het diervoederbedrijf - werd het uitsluiten van kinderarbeid als belangrijke vereiste genoemd. Binnen dit bedrijf vormen duurzaamheidsparameters een onderdeel van de bonussen en daarmee heeft het een impact op de medewerkers persoonlijk. De cateraar wilde de afhankelijkheid van, en impact op, natuurlijk kapitaal vooral weten vanuit een eigen motivatie om de prestaties ten aanzien van duurzaamheid verder te verbeteren. Voorkomen imagoschade of andere communicatie naar consumenten werd daarbij echter niet als belangrijk doel genoemd. Ook bij het zuivelbedrijf kwam de ambitie om klimaatneutraal te produceren meer voort uit een intrinsieke motivatie, dan om dit naar consumenten of NGO's te communiceren.

Diversiteit in de motivatie is ook bij de overige organisaties waar te nemen. De tapijtproducent gaf aan dat informatievoorziening omtrent natuurlijk kapitaal weliswaar door consumenten op prijs wordt gesteld, maar dat de missie an sich - om klimaatneutraal te worden en de ecologische voetafdruk te beperken - vooral de drijvende kracht is. De energieproducent gaf zelfs aan dat huishoudens nauwelijks geïnteresseerd zijn in duurzaamheidsprestaties en dat zij de keuze voor een aanbieder voornamelijk op de prijs baseren. Echter, NGO's zijn wel degelijk geïnteresseerd in de duurzaamheidsprestaties van dit bedrijf. Opvallend is dat het bij de financiële instelling eveneens de NGO's waren die inzicht verlangden in de interactie met natuurlijk kapitaal. Niet alleen van de eigen bedrijfsprocessen (gebouwen, transport, enzovoort) maar ook via de $\mathrm{CO}_{2}$-voetafdruk van de bedrijven die deze instelling faciliteert. De logistieke dienstverlener werkt ook aan duurzaamheid, maar doet dat in een complex samenspel van vele actoren en belangen. Het bedrijf moet continu omgaan met krachten die in verschillende richtingen trekken; van 'we moeten snel duurzamer worden' tot krachten die minder op milieu zijn gericht ('we moeten er wat mee doen').

Ten slotte hadden de intermediairs als motivatie dat zij bedrijven kunnen ondersteunen bij het meten van hun duurzaamheidsprestaties.

\subsection{Hoe: tools en data}

\section{Bedrijven die het nog lastig vinden}

Uit de interviews komt naar voren dat dit bedrijven zijn die erg geïnteresseerd zijn in tools en data, maar dat de mate waarin ze hier daadwerkelijk gebruik van maken nogal eens beperkt wordt door gebrek aan:

- tijd en middelen om data te verzamelen

- kennis.

Deze bedrijven werken vooral met certificaten en protocollen om duurzaamheid een sterkere rol in de besluitvorming te geven, zowel bij zichzelf evenals in de ketens waar ze werken. Het gebrek aan tijd en middelen is echter een complex vraagstuk indien én een veelheid aan producten wordt aangeboden, èn er een grote diversiteit aan ketenpartijen is. Als laatste schakel in de keten is het vaak niet te achterhalen hoe duurzaam voedsel is geproduceerd. Daar komt bij dat het voor de impact en afhankelijkheid van natuurlijk kapitaal ook nog uit kan maken in welke regio een product is geproduceerd, alsook in welke tijd van het jaar. Het is domweg niet haalbaar om voor alle producten de hele keten volledig te bestuderen op zijn interacties met natuurlijk kapitaal. Daarom werkt het merendeel van de voedingsbedrijven liever met keurmerken, certificaten en stappenplannen die doorlopen worden.

Bedrijven zouden wel betere informatie/data willen hebben over de productieprocessen eerder in de keten - want er wordt bijvoorbeeld wel eens getwijfeld aan het duurzame karakter van streekproducten - maar tracking en tracing is niet altijd mogelijk. Hierdoor is informatie over de interactie met natuurlijk kapitaal in de rest van de keten niet altijd transparant te maken. Transparantie omtrent sociaal kapitaal - zoals het uitsluiten van kinderarbeid - in de rest van de keten lijkt daarentegen wél voldoende te zijn, aldus de supermarktketen en de diervoederproducent.

Het energiebedrijf staat feitelijk nog aan het begin van het inzichtelijk krijgen van zijn impact op, c.q. de afhankelijkheid van natuurlijk kapitaal. Zij beschikt momenteel nog onvoldoende over de benodigde 
kennis om de interactie met natuurlijk kapitaal te kunnen kwantificeren. Het energiebedrijf is niet alleen erg geïnteresseerd om bijvoorbeeld te weten wat het effect van windmolens op de lokale biodiversiteit is, ${ }^{9}$ maar ook: wanneer is het effect acceptabel te noemen? Oftewel, waar ligt de grens? De NGO is kritisch over de tools uit het rapport Eco4Biz. Dit geldt ook voor de data: omdat er weinig echte dataverzameling heeft plaatsgevonden via veldwerk is de tijd rijp voor betere data. ${ }^{10}$ Een alternatieve tool is dan ook het ontwikkelen van stappenplannen voor bedrijven, waar ook gegevens voor moeten worden verzameld.

\section{Bedrijven die gebruik maken van tools en data}

Er zijn ook bedrijven die wel gebruik maken van tools die verder gaan dan protocollen en certificaten. Zo maakt de tapijtproducent gebruik van tools als LCA's en de zogenaamde Environmental Product Declaration (EPD) van de EU. De LCA-analyses worden hierbij in de hele keten toegepast. De ketens waar het bedrijf mee te maken heeft zijn relatief inzichtelijk en de informatie die gebruikt wordt is voldoende betrouwbaar. Bovendien wordt de dataverzameling steeds gemakkelijker omdat steeds meer partijen hieraan mee werken.

De financiële instelling gebruikt Sustainable Assessment Management en Sustainalytics. Sustainalytics is één van de vijf rating agencies die door de instelling benut wordt. Dit bedrijf baseert zich daarnaast ook op de Global Reporting Initiative en de richtlijnen van de International Integrated Reporting Council. De zuivelproducent heeft haar activiteiten door Arcadis laten toetsen via de tool 'Natural Capital Protocol'. Daar kwam uit dat het bedrijf op alle fronten aan dat protocol voldoet. Verder werkt dit bedrijf ook met de LEAP-aanpak van de FAO, wat vergelijkbaar is met de LCA-systematiek. De dataverzameling omtrent natuurlijk kapitaal is echter nog geen structureel gegeven bij deze zuivelproducent. De logistieke dienstverlener ten slotte gebruikt wel tools als LCA, onder meer voor biomassa, restwarmte en afbreekkosten.

Overigens is er ook kritiek op de LCA. Niet alleen is het voor bedrijven die een groot aantal soorten producten aanbieden ondoenlijk om voor elk product een LCA te maken, ook zou de LCA volgens de cateraar te veel vrijheidsgraden bieden om er - tot op zekere hoogte - zelf invulling aan te geven. De NGO merkte ook op dat het niet goed is dat LCA's vol vooronderstellingen zitten.

Resumerend kan worden vastgesteld dat bedrijven geïnteresseerd zijn in tools en data om inzicht te krijgen in hun interactie met natuurlijk kapitaal. Echter, bedrijven hebben niet altijd helder voor ogen hoe zo'n tool er precies uit moet zien en welke tools er al zijn. Vaak zijn gebrek aan tijd, middelen en kennis knelpunten om meer met tools te werken. Uit de interviews kan worden afgeleid dat een tool maatwerk vraagt op het schaalniveau van de sector. ${ }^{11}$ Met andere woorden: één generieke tool voor supermarkten (met zijn vele producten en lange ketens), één voor de energiesector, enzovoort. Als alle bedrijven binnen een sector gebruik zouden maken van dezelfde tool, bewerkstelligt dit een uniforme meetmethode. Het vervolgens verzamelen van data dient plaats te vinden op het schaalniveau van het individuele bedrijf. Met andere woorden, supermarktketen $A$ verzamelt data voor de grootheden van de generieke supermarkttool, supermarkten $B$ verzamelt zijn data, enzovoort. Als bedrijven hun specifieke bedrijfsdata invoeren in de generieke tool van hun sector, bewerkstellig je een uniforme meetmethode die het mogelijk maakt de interactie van bedrijven uit dezelfde sector onderling te vergelijken.

Welke tools en data gebruiken de geïnterviewde bedrijven?

In Tabel 2 van hoofdstuk 4 staat aangegeven welke tools, c.q. data de in de interviews betrokken organisaties gebruiken. Hieronder geven we er een bondig overzicht van. ${ }^{12}$

\footnotetext{
9 Het is opvallend dat er bij het energiebedrijf onvoldoende kennis is over de impact van windmolens op lokale biodiversiteit. In principe zou deze kennis vanuit onderzoeksinstituten beschikbaar moeten zijn. Mogelijk speelt hierbij dat het energiebedrijf nog aan het begin staat om dit inzicht te verkrijgen.

${ }^{10}$ De vraag kan gesteld worden of dit voor alle data geldt, of dat dit wellicht minder het geval is voor bijvoorbeeld data over Nederlandse cases.

${ }^{11}$ Volgens de NGO komt er momenteel ook steeds meer standaardisering per sector.

${ }^{12}$ In de bijlage staat weergegeven waar de afkortingen van deze tools voor staan.
} 
Tabel 1

Tools en data die organisaties gebruiken

\begin{tabular}{llll} 
Bedrijven & & Tools & Data \\
& Supermarkt keten & Schema's en stappenplannen & Doorlopen stappenplan \\
\cline { 2 - 4 } & Diervoederbedrijf & Certificering & Toetsing \\
\cline { 2 - 4 } & Cateraar & Keurmerken op basis van certificering & Toetsing \\
\cline { 2 - 4 } Zuivelproducent & Natural Capital Protocol, LCA en LEAP & Eigen datasystemen \\
\hline Tapijtermediair & NGO & Nog geen tools & Nog geen data \\
\hline Financiële instelling & & Stappenplannen & Doorlopen stappenplan \\
\hline Energieproducent & LCA en EPD & Vooral data voor LCA \\
\hline Logistieke dienstverlener & Sustainable Assessment Management & Data zijn ruimschoots aanwezig \\
\hline
\end{tabular}

\subsection{Wie: overheid versus bedrijfsleven}

Aan bedrijven werd ook gevraagd welke rol zij van de overheid verwachten. Voor wat betreft regelgeving en handhaving wees de supermarktketen erop dat zij in hun duurzaamheidsactiviteiten vaak vooruitliepen op de wetgeving. Een soortgelijk signaal gaven ook de diervoederproducent en de logistieke dienstverlener af: wettelijke kaders en regelgeving zouden meer nieuwe ontwikkelingen moeten toelaten. Volgens de zuivelproducent zou de overheid juist voor de achterblijvers op het terrein van natuurlijk kapitaal wet- en regelgeving in moeten zetten: de voorlopers op dit gebied zou de overheid daarentegen moeten belonen. Verder gaf de financiële instelling aan dat EZ de omslag in het denken in termen van natuurlijk kapitaal nog moet maken omdat zij met haar beleidsmaatregelen zoals budgetten en regelingen te veel focust op energie en te weinig op natuurlijk kapitaal. Ook de zuivelproducent gaf het signaal dat EZ meer met het bedrijfsleven zou moeten meedenken en meedoen als het gaat om duurzaamheid. De logistieke dienstverlener ging nog een stap verder door te stellen dat overheden weinig doen en er daarom niet op hen gewacht moet worden. Slechts een enkele organisatie - de tapijtproducent - gaf expliciet aan dat de overheid via regelgeving het gebruik van tools zou moeten verplichten.

Over het algemeen zien bedrijven vooral een rol voor de overheid in het opstellen van protocollen en tools voor het bepalen van het beslag/de afhankelijkheid van natuurlijk kapitaal. Een door overheden geïnitieerde en ondersteunde ontwikkeling van uniforme tools op sectorniveau zou het mogelijk maken interacties van bedrijven met natuurlijk kapitaal onderling te vergelijken. Daarbij is maatwerk gewenst: voor sectoren waar bedrijven één, c.q. een beperkt aantal producten aanbieden behoort een tool zoals het Natural Capital Protocol tot de mogelijkheden. Sectoren die in de keten eindaanbieder zijn van een groot aantal producten - denk aan de voedingssector - voelen meer voor een uniform systeem van keurmerken en certificaten. Het opstellen van protocollen en tools zou vanuit de overheid geïnitieerd kunnen worden in samenspraak met de totale keten. Dit zou het best in internationaal verband plaatshebben omdat producten vaak over de hele wereld worden geproduceerd.

Een ander type rol die werd genoemd betrof ondersteuning bij dataverzameling. Voor bijvoorbeeld voedingsbedrijven die aan het einde van de keten zitten is het lastig om voor al hun producten te achterhalen hoe duurzaam ze zijn geproduceerd, en dus of ze voldoen aan keurmerken en certificaten. Mede omdat hier kosten mee gemoeid zijn, zou een bijdrage van de overheid welkom zijn. Volgens de NGO laat de kwaliteit van data vaak te wensen over omdat er weinig echte dataverzameling plaatsvindt. Er worden nu vooral modeldata gebruikt, maar geen empirische data. En dat moet anders, aldus deze intermediair.

Verder bleek dat bedrijven vaak erg geïnteresseerd zijn in de uitkomst van onze studie, en ook dat zij mee zouden willen werken aan eventueel vervolgonderzoek. Vooral als dit ertoe zou leiden dat zij de interactie met natuurlijk kapitaal daardoor beter kunnen meten. 
Ten slotte geldt de kanttekening dat we hier waarschijnlijk met koplopers te maken hebben, ${ }^{13}$ die daardoor meer dan gemiddeld geïnteresseerd zijn in het stimuleren van transparantie en openheid omtrent de interactie met natuurlijk kapitaal. Een andere kanttekening is dat de geïnterviewde van de logistieke dienstverlener op persoonlijke titel sprak, en dus niet noodzakelijkerwijs de visie van het bedrijf vertegenwoordigde.

${ }^{13}$ Zo gaf bijvoorbeeld de tapijtproducent aan dat veel (mkb-)bedrijven niet of nauwelijks bekend zijn met het begrip natuurlijk kapitaal. 


\section{$4 \quad$ Conclusies}

\subsection{Algemene inzichten}

In dit hoofdstuk worden de belangrijkste bevindingen besproken, evenals dilemma's en vervolgstappen. Opgemerkt wordt dat de bij de interviews betrokken bedrijven tot de koplopers behoren. Er dient daarmee rekening te worden gehouden dat bij andere bedrijven mogelijk minder bewustzijn is omtrent de interactie met natuurlijk kapitaal. De bevindingen zijn:

- Geïnterviewde bedrijven noemen bij het beschrijven van natuurlijk kapitaal vaak de termen natuur, biodiversiteit, ecosystemen en in wat mindere mate grondstoffen. Ook duurzaamheid in het algemeen wordt met natuurlijk kapitaal in verband gebracht. Niet-herwinbare hulpbronnen worden hier echter meestal niet toe gerekend. Daarmee komt het beeld dat de meeste geïnterviewde bedrijven hebben bij natuurlijk kapitaal behoorlijk overeen met de wijze waarop PBL dit begrip hanteert binnen het project Natuurlijk Kapitaal Nederland. Daar waar verschillen zijn geconstateerd houden deze vaak verband met het type bedrijf en zijn producten. Wanneer een bedrijf wereldwijd produceert en daarbij grondstoffen gebruikt, ligt het meer voor de hand dat zij grondstoffen noemen als onderdeel van natuurlijk kapitaal. Ook wordt door internationale bedrijven vaker kinderarbeid genoemd als onderdeel van natuurlijk kapitaal (ook al valt dit feitelijk niet onder natuurlijk kapitaal).

- De geïnterviewde bedrijven zijn zeker geïnteresseerd om hun impact op en afhankelijkheid van natuurlijk kapitaal middels tools en data inzichtelijk te krijgen. Echter, bij deze bedrijven ontbreekt het nogal eens aan mogelijkheden om dit feitelijk te onderbouwen. Het gaat daarbij niet alleen om juiste kennis, alsook om de tijd en middelen die nodig zijn, zoals in het geval van een groot aantal producten die door vele ketenpartijen worden geproduceerd.

- De overheid zou ondersteuning kunnen bieden bij de ontwikkeling van tools en het verzamelen van data, dan wel bij de meer kwalitatieve methoden als protocollen en certificeringen. Dit zou ook de standaardisering van het meten ten goede moeten komen, en daarmee de mogelijkheid om bedrijven te vergelijken wat betreft hun impact op natuurlijk kapitaal. Daarbij is maatwerk op sectorniveau van belang: voor sectoren die een enkel product aanbieden is een omvangrijke doorrekening met bijvoorbeeld een LCA of de Natural Capital Protocol mogelijk. Echter, als productieprocessen vele ketenpartijen en/of producten bevatten - denk aan de voedingsindustrie dan liggen certificeringen en keurmerken meer voor de hand. Gezien de kosten hiervan werd in een interview hierbij een bijdrage van de overheid geopperd.

- Verder zouden tools het best op het schaalniveau van een sector ontwikkeld kunnen worden, en de data op het niveau van het bedrijf verzameld moeten worden. Daarnaast is data op gebiedsniveau van belang waar het gaat om effecten van productie op biodiversiteit.

- In principe zouden alle geïnterviewde bedrijven wel mee willen werken aan eventueel vervolgonderzoek. Bij bedrijven die expliciet aangaven hieraan mee te willen werken was vaak het argument dat zij daarmee hoopten de interactie met natuurlijk kapitaal beter te kunnen gaan meten.

\subsection{Resultaten en vervolgstappen}

Uit de verkregen inzichten komen ook een aantal dilemma's voort die hieronder staan weergegeven. Per dilemma worden ook mogelijke vervolgstappen benoemd.

\section{Gestandaardiseerde tools op sectorniveau ontbreken}

- Hoewel er diverse tools zijn ontwikkeld waarmee de afhankelijkheid van en impact op natuurlijk kapitaal kan worden ingeschat, blijkt dat het gebruik ervan door de geïnterviewde bedrijven toch nog te wensen over laat. Bedrijven vinden het benutten van dergelijke tools vaak ingewikkeld en duur.

- Onderlinge vergelijkbaarheid van bedrijven binnen eenzelfde sector wat betreft prestaties ten aanzien van behoud van natuurlijk kapitaal is van belang, maar standaardisering komt niet vanzelf op gang. 
Vervolgstappen

- Voor een aantal specifieke sectoren analyseren welke tools het meest geschikt zouden zijn. Is een LCA bijvoorbeeld wél toepasbaar voor een sector met een lange keten met één of enkele producten? Voor hoeveel producten met een korte keten lukt een LCA nog? Waar ligt de grens: wanneer liggen certificering en keurmerken meer voor de hand? Kortom, welk type tools zouden het best voor welke sectoren ontwikkeld kunnen worden?

- Aan de hand van literatuur en interviews kunnen de tools geselecteerd worden, en kan beschreven worden wat als plus- en minpunten wordt gezien. Daarbij is een relevante vraag wat nog zou moeten gebeuren om de bruikbaarheid van de tools te verbeteren, wat men ziet men als rol voor de overheid hierin en wat als rol voor het bedrijfsleven. En hoe organiseer je dat? Zouden NGO's bijvoorbeeld mee kunnen denken bij het ontwikkelen van gestandaardiseerde tools op sectorniveau? Welke rol zou de overheid daarin kunnen spelen?

\section{Beschikbaarheid van (betrouwbare) data is knelpunt}

- Data op gebiedsniveau, met name waar het gaat om biodiversiteit, ontbreekt veelal. Dit is met name genoemd door een energiebedrijf.

- Hoewel het verzamelen van bedrijfsspecifieke data voor bedrijven weliswaar minder problematisch is, is de vraag hoe betrouwbaar bedrijfsdata zijn, en hoe dit gecontroleerd zou kunnen worden.

\section{Vervolgstappen}

- Nagaan aan welke data behoefte is. Zijn deze data ergens aanwezig, maar niet toegankelijk? Of wel aanwezig, maar niet in de juiste vorm? Is in het voorzien van databehoefte ook een rol voor de overheid weggelegd? Of juist voor NGO's of kennisinstellingen of adviesbureaus?

- De mogelijkheden tot toetsing van bedrijfsdata onderzoeken aan de hand van interviews en literatuur.

\section{Veel bedrijven hebben nog weinig kennis van het begrip natuurlijk kapitaal}

Op basis van een steekproef van een aantal grote bedrijven die koplopers zijn, is in beeld gebracht welke tools ze gebruiken of zouden willen gebruiken. Er is daarmee echter nog geen zicht op in hoeverre dit beeld ook door andere bedrijven binnen hun sector wordt gedeeld, of hoe bedrijven uit andere sectoren hier tegen aankijken. Zo werd in een interview gesteld dat het mkb niet of nauwelijks bekend is met het begrip natuurlijk kapitaal.

\section{Vervolgstappen}

Aan de hand van interviews onder belangenorganisaties, koplopers en overige bedrijven binnen een aantal sectoren wordt geanalyseerd wat nodig is om niet alleen koplopers mee te krijgen, maar ook de mainstream bedrijven. Een vraag is ook of hier een rol voor de overheid is weggelegd, bijvoorbeeld door in kennis en bewustwording te voorzien? Aanbevelingen worden geformuleerd om tot de meest effectieve aanpak te komen.

\section{Natural Capital Protocol is nauwelijks genoemd in de interviews}

We hebben een eerste inzicht welke tools de geïnterviewde bedrijven prefereren die een beperkt aantal producten aanbieden met een korte keten. In de interviews is de Natural Capital Protocol weinig genoemd. Vooral de LCA - die met name de interactie met milieu meet - lijkt de voorkeur te hebben. Echter, de Natural Capital Protocol legt veel meer de nadruk op interactie met biodiversiteit en sluit daarmee beter aan op het begrip natuurlijk kapitaal.

\section{Vervolgstappen}

Aan de hand van interviews bekijken of de Natural Capital Protocol bekend is bij bedrijven en of ze van plan zijn dit in de toekomst te gaan gebruiken. Zo ja, wat zien ze als voordelen? Zo nee, wat zijn de belemmeringen? Heeft men ideeën voor verbeteringen dan wel aanvullingen?

Onderstaande tabel is een korte weergave van de onderzoeksvragen zoals die in de interviews door bedrijven zijn beantwoord: voor een genuanceerd beeld hiervan wordt naar de hoofdtekst verwezen. 


\section{Tabel 2}

Korte samenvatting beantwoorden onderzoeksvragen door bedrijven.

\begin{tabular}{|c|c|c|c|c|c|}
\hline Organisatie & $\begin{array}{l}\text { Definities: wat verstaat } \\
\text { u onder natuurlijk } \\
\text { kapitaal? }\end{array}$ & $\begin{array}{l}\text { Motivatie: waarom willen } \\
\text { meten? }\end{array}$ & $\begin{array}{l}\text { Tools en data: worden deze } \\
\text { gebruik? Zo ja, welke en hoe? }\end{array}$ & $\begin{array}{l}\text { Zijn er belemmeringen / kansen } \\
\text { ten aanzien van meten }\end{array}$ & $\begin{array}{l}\text { (gevraagde) rol overheid / } \\
\text { bedrijf (wat is een } \\
\text { bedrijfstaak en wat is een } \\
\text { overheidstaak) }\end{array}$ \\
\hline
\end{tabular}

Supermarktketen

Een gezond ecosysteem,

c.q. de flora en fauna

duurzaamheidskenmerken van

producten naar de consument te

communiceren. Anders heeft meten

/ onderzoek vooral een preventieve

functie, zoals het uitsluiten dat

kinderarbeid ergens in de keten

heeft plaatsgehad.

Energieproducent

Natuur en biodiversiteit,

het algemeen.

Het past in de missie 'duurzame

dergelijke informatie interessant

voor de klantengroep NGO's.

Huishoudens zijn hier overigens

Er wordt gewerkt met schema's

- Gezien de veelheid van producten en de lange keten is voor elk product

duurzaamheidskenmerken meten

niet mogelijk

- Een kans is te stimuleren dat alle bedrijven aan de hand van vaste indicatoren in hun jaarverslagen rapporteren over duurzaamheid.

in samenspraak met de keten in internationaal overheid.

natuur en biodiversiteit.

nauwelijks in geïnteresseerd.

Cateringbedrij Biodiversiteit in de brede Meten is weten: inzicht in de

zin, dat wil zeggen inclusief van productieprocessen op

bijvoorbeeld koe rassen en natuurlijk kapitaal zou het

bloemrijke bermen

cateringbedrijf in staat stellen om

hun eigen prestaties op

duurzaamheid verder te verbeteren. bronnen, inclusief wind-

waterkracht en zonne-

Een puur commercieel belang: het bureau wil het gebruiken om advies en -trainingswerkzaamheden mee energie.

Het bedrijf heeft nog onvoldoende kennis over de impact /

Meer ondersteuning vanuit de overheid op het terrein van kennis omtrent de impact op natuur en biodiversiteit.

De energieproducent doet al wat naar de impact op$$
\text { natuur en biodiversiteit. }
$$

De overheid zou kunnen

keurmerken op basis Het daadwer

ondersteunen bij het achterhalen

we dat niet

producten kunnen doen, en ii) het is hoe duurzaam voedsel is

uberhaupt voor ons als laatste in de geproduceerd.

keten vaak lastig is te achterhalen

waar een product precies vandaan

komt.

Het bureau ontwikkelt zelf geen rekenmodellen maar zou in haa adviserende rol bij processen rondom natuurlijk kapitaal graag gebruik maken van rekentools.
Het bureau ontbeert

wetenschappelijke modellen en

tools om haar advieswerk omtrent

natuur en biodiversiteit te

ondersteunen.
Het goed zijn als overheden bedrijven stimuleren en

faciliteren om informatie omtrent hun beslag op natuurlijk kapitaal naar buiten te brengen. Dit zou de aantasting van natuur en biodiversiteit kunnen bepreken. 


\begin{tabular}{|c|c|c|c|c|c|}
\hline Organisatie & $\begin{array}{l}\text { Definities: wat verstaat } \\
\text { u onder natuurlijk } \\
\text { kapitaal? }\end{array}$ & $\begin{array}{l}\text { Motivatie: waarom willen } \\
\text { meten? }\end{array}$ & $\begin{array}{l}\text { Tools en data: worden deze } \\
\text { gebruik? Zo ja, welke en hoe? }\end{array}$ & $\begin{array}{l}\text { Zijn er belemmeringen / kansen } \\
\text { ten aanzien van meten }\end{array}$ & $\begin{array}{l}\text { (gevraagde) rol overheid / } \\
\text { bedrijf (wat is een } \\
\text { bedrijfstaak en wat is een } \\
\text { overheidstaak) }\end{array}$ \\
\hline Tapijtproducent & $\begin{array}{l}\text { De } 3 \text { P's van duurzaamheid } \\
\text { vallen hieronder. }\end{array}$ & $\begin{array}{l}\text { - In aansluiting op de missie om } \\
\text { klimaat-neutraal te worden en de } \\
\text { ecologische voetafdruk zoveel } \\
\text { mogelijk te beperken, wordt } \\
\text { standaard bekeken hoe met de } \\
\text { grondstoffen om te gaan en hoe } \\
\text { de milieubelasting daarvan } \\
\text { teruggebracht kan worden. } \\
\text { - Het wordt ook door consumenten } \\
\text { op prijs gesteld }\end{array}$ & $\begin{array}{l}\text { Vooral LCA's, maar ook de } \\
\text { Environmental Product Declaration } \\
\text { (EPD) van de EU. }\end{array}$ & $\begin{array}{l}\text { - De LCA-analyses bieden de } \\
\text { mogelijkheid producten en } \\
\text { grondstoffen die gebruikt worden } \\
\text { te vermelden op de site. } \\
\text { - De dataverzameling wordt steeds } \\
\text { makkelijker omdat meer partijen } \\
\text { zich hiermee bezig houden. }\end{array}$ & $\begin{array}{l}\text { - Bedrijven ondersteunen bij } \\
\text { informatievoorziening omtrent } \\
\text { natuurlijk kapitaal, zoals de } \\
\text { uitwisseling van informatie } \\
\text { tussen ketenpartijen. } \\
\text { - De overheid zou tenslotte ook } \\
\text { relevante keurmerken kunnen } \\
\text { ondersteunen en promoten. } \\
\text { - EZ zou bedrijven kunnen } \\
\text { verplichten om de EPD te gaan } \\
\text { hanteren. }\end{array}$ \\
\hline Financiële instelling & $\begin{array}{l}\text { Schaarse grondstoffen en } \\
\text { energie en de vertaling } \\
\text { naar eisen aan krediet } \\
\text { verlening }\end{array}$ & $\begin{array}{l}\text { NGO's verlangde dat de instelling } \\
\text { inzichtelijk maakte wat de } \mathrm{CO}_{2} \\
\text { footprint was van bedrijven die zij } \\
\text { faciliteert met leningen en credit. }\end{array}$ & $\begin{array}{l}\text { De instelling gebruikt Sustainable } \\
\text { Assessment Management en } \\
\text { Sustainalytics. Het bedrijf baseert } \\
\text { zich ook op de Global Reporting } \\
\text { Initiative en de richtlijnen van de } \\
\text { International Integrated Reporting } \\
\text { Council. }\end{array}$ & $\begin{array}{l}\text { - Kans: Het wordt allemaal steeds } \\
\text { meer NK-inclusief, het niet- } \\
\text { betrekken van NK betekent dat } \\
\text { men de verkeerde kant op gaan. } \\
\text { - Belemmering: er zijn genoeg } \\
\text { tools, maar er moet wel actief } \\
\text { mee gewerkt worden, er moet } \\
\text { een mind set zijn }\end{array}$ & $\begin{array}{l}\text { EZ heeft bij budgetten en } \\
\text { regelingen de focus vooral op } \\
\text { energie liggen en minder op } \\
\text { NK. } \\
\text { - Voor de overheid is het zaak } \\
\text { om de wetgeving consistent } \\
\text { maken met het denken vanuit } \\
\text { NK en de circulaire economie. }\end{array}$ \\
\hline Diervoederproducent & $\begin{array}{l}\text { Dit is de samenhang } \\
\text { tussen: } \\
\text { 1. grondstoffen } \\
\text { (duurzaam); } \\
\text { 2. productie (zoals geen } \\
\text { kinderarbeid); } \\
\text { 3. producten; } \\
\text { 4. } \text { commitment (ook van } \\
\text { stakeholders). }\end{array}$ & $\begin{array}{l}\text { Tools zijn ervoor om te } \\
\text { kwantificeren hoeveel minder } \\
\text { emissies je bijvoorbeeld realiseert. }\end{array}$ & $\begin{array}{l}\text { - Tools: geen tools zoals LCA, maar } \\
\text { wel certificering } \\
\text { - Data: kwaliteit van data kan vaak } \\
\text { beter. Van bijvoorbeeld } \\
\text { mainstream soja is een heel klein } \\
\text { deel slecht voor de regenwouden, } \\
\text { maar welk deel dit precies is, is } \\
\text { niet eenvoudig te bepalen. }\end{array}$ & $\begin{array}{l}\text { - Tools dienen meer maatwerk te } \\
\text { bieden } \\
\text { - Tools zijn niet altijd } \\
\text { gebruiksvriendelijk voor een } \\
\text { bedrijf }\end{array}$ & $\begin{array}{l}\text { - De overheid dient } \\
\text { kennisontwikkeling te } \\
\text { faciliteren; } \\
\text { - De wettelijke kaders en } \\
\text { regelgeving moeten } \\
\text { bijvoorbeeld meer nieuwe } \\
\text { technologieën toelaten }\end{array}$ \\
\hline
\end{tabular}




\begin{tabular}{|c|c|c|c|c|}
\hline Organisatie & $\begin{array}{l}\text { Definities: wat verstaat } \\
\text { u onder natuurlijk } \\
\text { kapitaal? }\end{array}$ & $\begin{array}{l}\text { Motivatie: waarom willen } \\
\text { meten? }\end{array}$ & $\begin{array}{l}\text { Tools en data: worden deze } \\
\text { gebruik? Zo ja, welke en hoe? }\end{array}$ & $\begin{array}{l}\text { Zijn er belemmeringen / kansen } \\
\text { ten aanzien van meten }\end{array}$ \\
\hline NGO & $\begin{array}{l}\text { De voorraad goederen en } \\
\text { diensten die uit de natuur } \\
\text { komen: 'Stocks \& flows } \\
\text { provided by nature'. }\end{array}$ & $\begin{array}{l}\text { Als het gaat om duurzaamheid was } \\
\text { er altijd 'leunen op de overheid'. Nu } \\
\text { moeten bedrijven het doen: meten } \\
\text { is weten hoe goed ze het doen. }\end{array}$ & $\begin{array}{l}\text { Niet zozeer de tools zoals } \\
\text { beschreven in Eco4Biz, maar meer } \\
\text { het ontwikkelen van stappenplannen }\end{array}$ & $\begin{array}{l}\text { - Het probleem met tools in } \\
\text { Eco4Biz is dat ze vaak te } \\
\text { algemeen en te ingewikkeld zijn } \\
\text { voor de bedrijven. } \\
\text { - Veldwerk en echte data } \\
\text { verzamelen is iets wat weinig } \\
\text { gebeurd. }\end{array}$ \\
\hline Zuivelproducent & Biodiversiteit & $\begin{array}{l}\text { De zuivelproducent heeft de ambitie } \\
\text { om klimaatneutraal te gaan } \\
\text { produceren. Naar consumenten of } \\
\text { NGO's communiceert het bedrijf niet } \\
\text { expliciet over duurzaamheid en } \\
\text { natuurlijk kapitaal. }\end{array}$ & $\begin{array}{l}\text { - Men gebruikt de 'Natural Capital } \\
\text { Protocol'. } \\
\text { - Verder werkt het bedrijf ook met } \\
\text { LEAP die vergelijkbaar is met } \\
\text { LCA. }\end{array}$ & $\begin{array}{l}\text { - De zuivelproducent voldoet naar } \\
\text { eigen zeggen op alle fronten aan } \\
\text { het Natural Capital Protocol. } \\
\text { - Het verzamelen van data omtrent } \\
\text { natuurlijk kapitaal heeft echter } \\
\text { nog geen structurele plek } \\
\text { gekregen binnen het bedrijf. }\end{array}$ \\
\hline
\end{tabular}

ogistieke dienstverlener (op Biodiversiteit en persoonlijke titel)
Biodiversiteit
Motivaties lopen uiteen, veel aandacht voor $\mathrm{CO}_{2}$-emissies en

internationale maatstaven.
LCA en MER maar meer in relatie tot Een belemmering is dat het bedrijf restwarmte en afbreekkosten.
- De overheid zou voor de achterblijvers op het terrein van natuurlijk kapitaal, wet- en regelgeving in moeten zetten: de voorlopers op dit gebied zou de overheid juist moeten belonen.

- EZ zou meer met het bedrijfsleven moeten meedenken en meedoen omtrent duurzaamheid.

- Meer actief zijn ten aanzien van natuurlijk kapitaal, bijvoorbeeld via regelgeving. 


\section{Literatuur en websites}

Arkel, G. van en J. Jonker, 2012. Duurzaam innoveren = inspireren en accelereren. Working Paper nr. 25 in de serie 'Duurzaam Organiseren $\rightarrow$ Doen!' Nijmegen School of Management in samenwerking met Kluwer.

Breman, B., E. de Lijster, D. Kamphorst en N. de Sena. Betrokkenheid van Bedrijven bij Natuur in Nederland. Wageningen UR, WOt Natuur en Milieu, paper 36.

Burg, S.W.K. van den en M.J. Bogaardt, 2014. Business and Biodiversity: A frame analysis. Ecosystem Services, 178-184.

Dirkx, J. en B. de Knegt, 2014. Natuurlijk Kapitaal als nieuw Beleidsconcept. Balans van de Leefomgeving 2014 - deel 7. Den Haag, Planbureau voor de Leefomgeving.

Heide, M. van der, W. Heijman en J. Schaminée. 2015. Ecologische Economie. Ede, Ontwikkelcentrum. Het Groene Brein, MVO Nederland en Platform BEE. 2015. Natuurlijk Kapitaal: Een Gedeelde Basis. Beschikbaar via internet:

http://www. platformbee.nl/assets/Natuurlijk-Kapitaal-Een-Gedeelde-Basis-2015-digitaal.pdf. http://themasites. pbl.nl/natuurlijk-kapitaal-nederland/achtergronden/wat-is-natuurlijk-kapitaal http://www.naturalcapitalcoalition.org/why-natural-capital/natural-capital.html

Jorgensen, S.E., F-L. Xu en R. Constanza. 2010. Handbook of ecological indicators for assessment of ecosystem health. CRC Press, New York, U.S.A.

Leenders, C. van en A.-M. Bor. 2014. Bedrijven en Biodiversiteit. Inzichten uit Community of Practice. Beschikbaar via internet:

https://www.duurzaamdoor.nl/sites/default/files/Bedrijven\%20en\%20Biodiversiteit\%20\%20printversie_0.pdf.

Ministerie van EZ. 2013. Uitvoeringsagenda Natuurlijk Kapitaal: Behoud en duurzaam Gebruik van Biodiversiteit. Den Haag, Brief aan de Tweede Kamer.

Ministerie van EZ. 2014. Natuurlijk verder; Rijksnatuurvisie 2014. Den Haag.

Oosterhuis, F. en A. Ruijs. 2015. Natuurlijk Kapitaal Nederland. Een conceptuele Verkenning en Afbakening van het TEEB-Kader. Bilthoven, PBL.

WBCSD. 2013. Eco4Biz: Ecosystem services and biodiversity tools to support business decisionmaking. Version 1. 


\section{Bijlage 1 Afkortingen voluit geschreven}

\begin{tabular}{ll} 
Tools & Voluit \\
Afkorting & Levenscyclusanalyse \\
\hline LCA & Livestock Environmental Assessment and Performance \\
\hline LEAP & Environmental Product Declaration \\
\hline EPD & Milieueffectrapportage \\
\hline MER & \\
\hline Overig & Voluit \\
\hline Afkorting & Biodiversiteit, Ecosystemen en Economie \\
\hline (Platform) BEE & Maatschappelijk Verantwoord Ondernemen \\
\hline MVO (Nederland) &
\end{tabular}


LEI Wageningen UR

Postbus 29703

2502 LS Den Haag

T 0703358330

E publicatie.lei@wur.nl

www.wageningenUR. nl/lei

\section{Rapport}

LEI 2016-060
LEI Wageningen UR is een onafhankelijk, internationaal toonaangevend, sociaaleconomisch onderzoeksinstituut. De unieke data, modellen en kennis van het LEI bieden opdrachtgevers op vernieuwende wijze inzichten en integrale adviezen bij beleid en besluitvorming, en dragen uiteindelijk bij aan een duurzamere wereld. Het LEI maakt deel uit van Wageningen UR (University \& Research centre). Daarbinnen vormt het samen met het Departement Maatschappijwetenschappen van Wageningen University en het Wageningen UR Centre for Development Innovation de Social Sciences Group.

De missie van Wageningen UR (University \& Research centre) is 'To explore the potential of nature to improve the quality of life'. Binnen Wageningen UR bundelen 9 gespecialiseerde onderzoeksinstituten van stichting DLO en Wageningen University hun krachten om bij te dragen aan de oplossing van belangrijke vragen in het domein van gezonde voeding en leefomgeving. Met ongeveer 30 vestigingen, 6.500 medewerkers en 10.000 studenten behoort Wageningen UR wereldwijd tot de aansprekende kennisinstellingen binnen haar domein. De integrale benadering van de vraagstukken en de samenwerking tussen verschillende disciplines vormen het hart van de unieke Wageningen aanpak. 

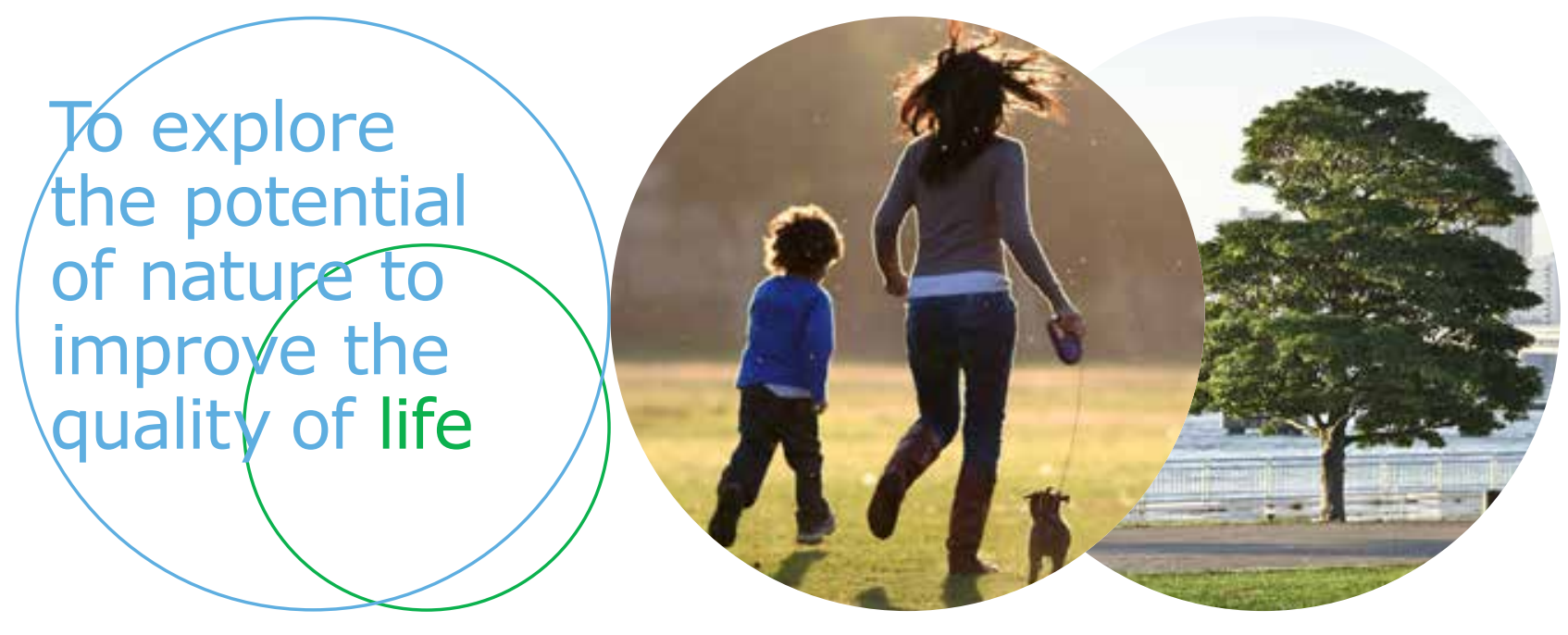

LEI Wageningen UR

Postbus 29703

2502 LS Den Haag

E publicatie.lei@wur.nl

www.wageningenUR.nl/lei

RAPPORT

LEI 2016-060

ISBN 978-94-6257-839-5
LEI Wageningen UR is een onafhankelijk, internationaal toonaangevend, sociaaleconomisch onderzoeksinstituut. De unieke data, modellen en kennis van het LEI bieden opdrachtgevers op vernieuwende wijze inzichten en integrale adviezen bij beleid en besluitvorming, en dragen uiteindelijk bij aan een duurzamere wereld. Het LEI maakt deel uit van Wageningen UR (University \& Research centre). Daarbinnen vormt het samen met het Departement Maatschappijwetenschappen van Wageningen University en het Wageningen UR Centre for Development Innovation van de Social Sciences Group.

De missie van Wageningen UR (University \& Research centre) is 'To explore the potential of nature to improve the quality of life'. Binnen Wageningen UR bundelen 9 gespecialiseerde onderzoeksinstituten van stichting DLO en Wageningen University hun krachten om bij te dragen aan de oplossing van belangrijke vragen in het domein van gezonde voeding en leefomgeving. Met ongeveer 30 vestigingen, 6.500 medewerkers en 10.000 studenten behoort Wageningen UR wereldwijd tot de aansprekende kennisinstellingen binnen haar domein. De integrale benadering van de vraagstukken en de samenwerking tussen verschillende disciplines vormen het hart van de unieke Wageningen aanpak. 